\title{
HERPETOFAUNAL DIVERSITY AND COMMUNITY STRUCTURE IN THE MURCHISON FALLS-ALBERT DELTA RAMSAR SITE, UGANDA
}

Mathias Behangana ${ }^{1}$, Richard Magala ${ }^{2,10}$, Raymond Katumba ${ }^{3}$, David Ochanda ${ }^{4}$, Stephen Kigoolo $^{5}$, Samuel Mutebi ${ }^{6}$, Daniele Dendi ${ }^{7,8,9}$, LuCA Luiselli ${ }^{7,8,9}$ And Daniel F. Hughes ${ }^{11}$

${ }^{1}$ Department of Environmental Sciences, Makerere University, P.O. Box 7062, Kampala, Uganda; E-mail:mbehangana@gmail.com

${ }^{2}$ Department of Geography and Environmental Management, Liverpool University Hope

University,L169JD, UK, E-mail: magalarich20@gmail.com

${ }^{3}$ Department of Wildlife and Animal Resources Management (WARM), Makerere University P.O. Box 7062, Kampala,Uganda; E-mail: raykatumba21@gmail.com

${ }^{4}$ Total E \& P Uganda, Department of Environment and Social Affairs, P.O. Box 34867, Kampala, Uganda; E-mail: david.ochanda@total.com

${ }^{5}$ Biodiversity Solutions Ltd, P.O. Box, 22587, Kampala, Uganda; E-mail: skigoolo@yahoo.com ${ }^{6}$ Q-Sourcing Servtecfor Total E \& P Uganda, Department of Environment and Social Affairs, P.O. Box 34867, Kampala, Uganda; E-mail: samuel.mutebi@external.total.com/samuelmutebi001@ gmail.com

${ }^{7}$ Institute for Development, Ecology, Conservation, and Cooperation, via G. Tomasi di Lampedusa 33, I-00144 Rome, Italy; E-mails:d.dendi@ideccngo.org; l.luiselli@ideccngo.org ${ }^{8}$ Department of Applied and Environmental Biology, Rivers State University of Science and Technology, P.M.B. 5080, Port Harcourt, Nigeria

${ }^{9}$ Department of Zoology, Faculty of Sciences, University of Lomé, Lomé, Togo

${ }^{10}$ Department of Natural Resource Ecology and Management, Iowa State University, Ames, IA, 50011, USA.

${ }^{11}$ Department of Biology, Coe College, 1220 1st Avenue NE, Cedar Rapids, IA 52402, USA; E-mail:dhughes@coe.edu

Abstract.

1. The area of the Murchison Falls-Albert Delta is among the most important for conservation in East Africa due to the high species richness, and the presence of several endemic species of conservation concern.

2. Here, we report a study on the diversity patterns and community structure of the herpetofauna of this area.

3. Field studies were conducted in the Albert Nile Delta Ramsar site between $1^{\text {st }}$ October 2017 and $9^{\text {th }}$ September 2018. The data collection relied on Visual Encounter Surveys (VES), pitfall trapping, and dip netting. Descriptive statistics, i.e. species numbers in each transect were used as a measure of the present biodiversity, whereas Chaol and Chao species estimator algorithms were used to predict the potential number of species found in each site/habitat.

4. A total of 898 individuals representing 25 reptile species belonging to four orders, 15 families, and 20 genera were recorded during the 12 months of surveys.

5. The data shows some non-random spatial and temporal patterns whereby there is a cyclic reptilian diversity peaking during the December-March and again towards June-August-September which are peaks of the dry season.

6. The most frequently encountered species were Varanus niloticus, Crocodylus niloticus, Agama agama, Trachylepis maculilabris, and Lygodactylus guttularis, which accounted for almost $90 \%$ of all recorded individuals.

7. A total of 27 amphibian species, belonging to nine families and 10 genera were recorded during the period of the survey. The diversity and abundance graphs would indicate amphibians having bimodal peaks (September-December, and March-May). The diversity seemed to dip during the dry season months - which is the opposite case for reptiles.

Key words: Amphibia; Reptilia; diversity metrics; Albert Delta; Murchison Falls; Red List. 


\section{INTRODUCTION}

The Murchison Falls-Albert Delta Wetland System, Uganda, is Ramsar Site No. 1640 (https://www. ramsar.org/document/ramsar-advisory-mission-report-90-uganda-2018). It lies within the Lake Albert Basin and falls almost entirely within the boundaries of the Murchison Falls National Park, with an area of about 17,293 ha, located at $01^{\circ} 57^{\prime} \mathrm{N} 031^{\circ} 42^{\prime} \mathrm{E}$ in $\mathrm{Bu}-$ liisa and Nwoya Districts. The site stretches from the top of Murchison Falls, where the River Nile flows through a rock cleft some $6 \mathrm{~m}$ wide, to the delta at its confluence with Lake Albert. The exception to this is a one-kilometer wide band of land measured from the southern bank of the Nile River running from the western boundary of the national park to the point at which the river joins Lake Albert. The end of the Ramsar Site here can also be located as the western edge of the inland delta formed by the Nile River's entry to Lake Albert (https://www.ramsar.org/document/ramsar-advisory-mission-report-90-uganda-2018). It is important as a spawning ground for Lake Albert fisheries, supports globally threatened bird species, and provides wetland habitat for biodiversity during the dry seasons. It is an area of high species diversity and endemism making it a critical area for wildlife at the regional scale. However, with the impending oil exploration and production by the government of Uganda and human pressures on the south bank of the Nile river (Behangana et al. 2017), the diversity and community structure of herpetofauna appears to be potentially under threat. Therefore, understanding the diversity and community structure of reptiles and amphibians in the Delta area of Murchison Falls is essential for supporting conservation policies, guiding mitigation measures and, more importantly, providing data for species diversity monitoring (Brauneder et al. 2018).

The need to quantitatively assess the diversity and community structure of herpetofauna is also supported by the fact that there have been very few field surveys on amphibians and reptiles in the Murchison Falls-Albert Delta Wetland System, with most studies focusing on the ecology, population biology and conservation of the Nile crocodile Crocodylus niloticus (Hutton 1991; Baguma 1996; Thorbjarnarson \& Shirley 2009; Behangana 2014; Behangana et al. 2017). Apart from crocodiles, this site is inhabited by other reptile species, including the Nile monitor (Varanus niloticus) as well as the threatened Nile Soft-shelled Turtle (Trionyx triunguis), which is considered to be CR B1ab (i, ii, iii, iv) in Uganda's national red list (Behangana 2014). Other species considered as threatened according to Uganda's red list include $P e$ lusios adansonii CR B1ab (ii, iii) and P. chapini CR $\mathrm{B} 1 \mathrm{ab}$ (ii, iii), which are also likely to be in the area of the Delta Ramsar Area as they had been recorded in adjacent habitats (MB, pers. obs.). According to Rhodin et al. (2017), Pelusios adansonii is not known from Uganda, but Spawls et al. (2018) report that it likely occurs in northwestern Uganda. As for P. chapini, Rhodin et al.'s (2017) distribution map seems to overlap with a large portion of western Uganda near Lake Albert and this is confirmed by Spawls et al. (2018). On the other hand, no amphibian species of conservation concern have been recorded in the Murchison Falls-Albert Delta Wetland System. Thus, the scientific knowledge on the structure and organization of the reptile and amphibian communities of the area (species richness, dominance, evenness) remains anecdotal.

In this paper we quantitatively analyze, for the first time in the international scientific literature, the species composition, diversity and community metrics of the herpetofauna in the Murchison Falls-Albert Delta Wetland System by reporting field data collected throughout twelve months, covering the end of the wet season in 2017 and to the beginning of the dry season in 2018. Although the field study was designed to provide baseline data against which oil and gas exploration and development activities would be assessed, nonetheless it provided noteworthy insights into the community ecology of herpetofauna in tropical East Africa.

\section{Study Area}

The Murchison Falls-Albert Delta Wetland System lies on the Victoria Nile and is between 300-500 metres in width, has a strong current flowing from east to west, and stretches from below the falls to an area where the river becomes shallow as it enters Lake Albert and the Victoria Nile Delta, a distance of over 27 kilometers (WMD/NU, 2008). The site is situated within the Murchison-Semliki Landscape with a "tropical wet and dry or savanna climate" (Aw) according to the Köppen climate classification (e.g. Peel et al. 2007). The distinct dry season characteristic for this class of climate is less pronounced in the landscape and daily maximum temperatures remain relatively low because of its average elevation above a thousand meter which has a cooling effect. Mean 
annual rainfall ranges between $1350-1600 \mathrm{~mm}$ distributed over two distinct rainy seasons from April to May and from October to December. The mean annual temperature ranges between $23-29{ }^{\circ} \mathrm{C}$ and $\max 31{ }^{\circ} \mathrm{C}$ (see Peel et al. 2007). Evapotranspiration (moisture loss from evaporation and transpiration from plants) is relatively low for an Aw climate due to moderate maximum daily temperatures in the dry season $\left(<30^{\circ} \mathrm{C}\right)$ (Peel et al. 2007) The habitat along the river is dominated by Vossia cuspidata (Hippo grass) and Cyperus papyrus with tree cover behind. Some parts of the riverbanks are lined by gallery forest/woodland. Several islands are present in the river, some of which are large, over $2 \mathrm{~km}^{2}$, or more. These islands support a range of vegetation communities; papyrus, swamp reeds, tall grass, a few trees while others are of short, grazed grass which is favored as habitat by various fauna including mammals, birds, herpetofauna, and insects. The geographic scope of the surveys covered the whole delta area of the Murchison Falls-Albert Nile Delta Ramsar site (Fig. 1).

Five transects were demarcated and surveyed, each transect surveyed on a monthly basis from the same starting to the ending point, for the entire 12 months. The various sampling sites were reached by a small boat. Surveys covered at least five days during each month, with two days on the land transects and three days on the river channel transects. In addition to transect surveys, two days of pitfall trapping along the land transects on either bank of the river were added in each month of the survey. Details of the study transects are given in supplementary materials Table S1. All Delta Channel transects start from around Pipeline Crossing North (PCN) to the lakeside (Table S1). The Delta Channel transects covered all navigable areas where the small boat could reach including the floating islands overlooking Panyimur and Wanseko. Not all the waters of the

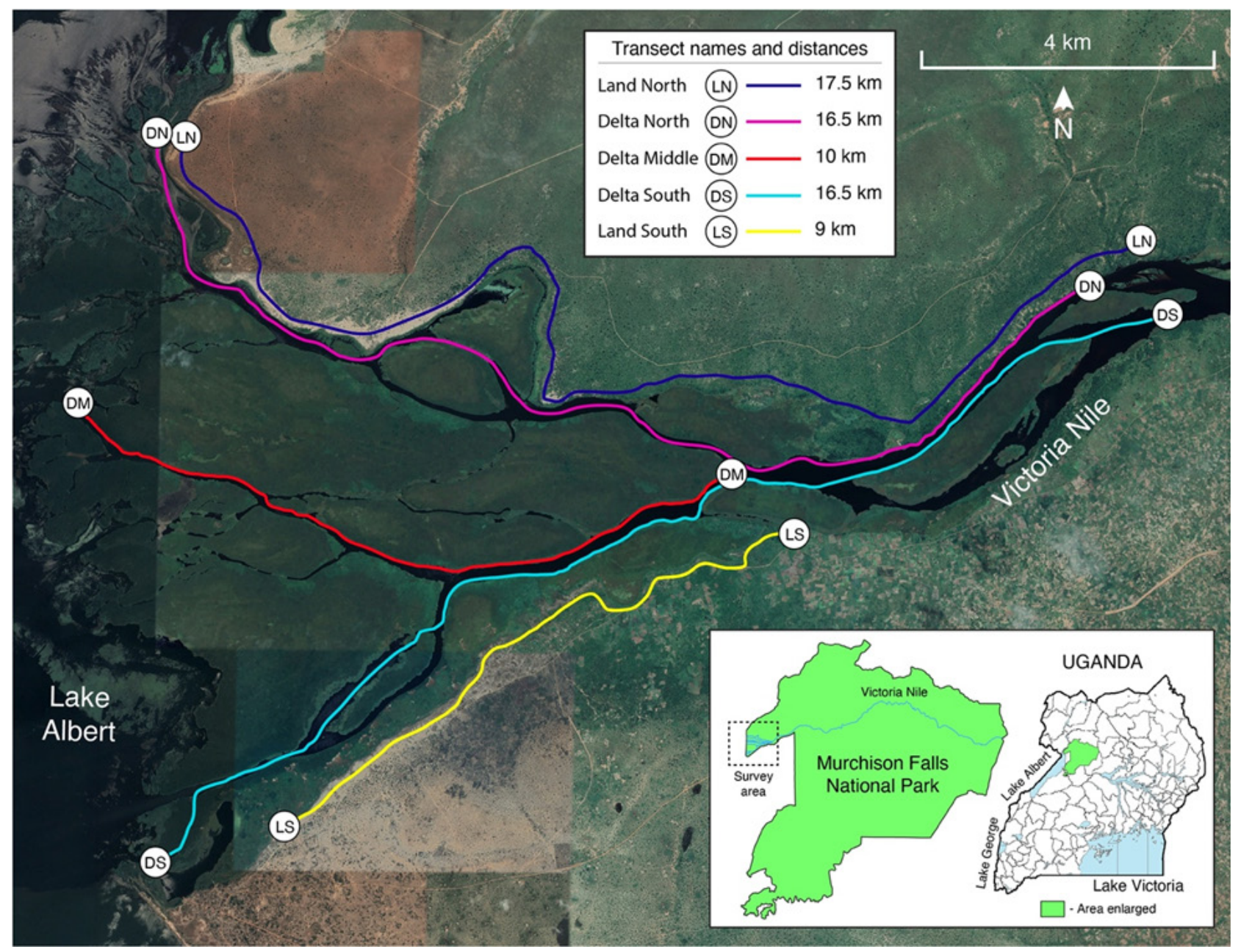

Figure 1. Map of the Murchison Falls-Lake Albert Delta Wetland System showing the study transects. Symbols: LS = Land Transect South (LTS), DS = Delta Channel South (DCS), DM = Delta Channel Mid (DCM), DN = Delta Channel North (DCN), LN = Land Transect North (LTN) 
Ramsar site were surveyed because some areas were very shallow (some channels of the main ones and the open waters at the river mouth lakewards) and not accessible even by small boat.

\section{MethodS \\ 2.1. Species identification}

Identification of herpetofauna followed Schiøtz (1999), Spawls et al. (2002; 2006; 2018), and Channing \& Howell (2006). AmphibiaWeb (2017) and The Reptile Database (Uetz \& Hošek 2018) were also used. The taxonomy of several African species is still under debate. Concerning Agama agama, it should be remarked that the taxonomy of this species complex is still unresolved, and that, according to some authorities, other species may occur in Uganda (Leaché et al. 2016; Spawls et al. 2018). The conservation status of the herpetofauna is reported using the IUCN Red Listing (IUCN, 2018) and the Ugandan Red List (WCS, 2016).

\subsection{Field protocol}

Three methods were applied in the field study: Visual Encounter Surveys (VES), Pitfall Trapping, and Dip Netting. All these methods were applied only during daytime, owing to health and safety issues raised by the funder with respect to night surveys. Ground-truthing marked out one kilometer stretches for future reference along each transect. All coordinates for sampling locations and routes during fieldwork were marked using a portable GPS (Garmin) and expressed in UTM-WGS 84 system. Every amphibian or reptile individual recorded was thus referenced to its current location and to these sections of transects.

The surveys were habitat based. Key amphibian and reptilian habitats were stratified for ease of sampling along each of the five transects sampled. The key habitats for amphibians focused on for the purposes of the surveys included lentic habitats and vegetated wetlands. Suitable habitats for reptiles included vegetated riverbanks, rocky outcrops, big trees and woodlands. Edges of riverbanks were carefully monitored for any sun-basking reptiles.

Visual Encounter Surveys (VES, sensu Heyer et al. 1994) were carried out on foot and by boats. Potential retreat sites (stones, woods, cover objects) were inspected in order to find any concealed specimens. Anuran species whose audio calls were known by the main author were used to locate and record the associated species. Each transect would be split into sections depending on the dominant vegetation types and for land transects, each section walked for one hour while documenting any herpetofauna observed while boats were used for water transects. Two boats were used during the survey - a large boat with a 315 Horse Power engine in the open waters and as support to a smaller one with a 15 Horse Power engine that was used to access the shallower waters and sometimes coming to the edges of the river banks. Daytime counts of reptiles were conducted along the three channels of the Ramsar Delta area by use of a small engine boat because of its maneuverability and ability to access the shallower waters. All surveys started from a marked point upstream. A group of three researchers would sit at locations on the starboard side (right side when looking forward toward the bow) of the boat and look out for any herpetofauna. On sighting an individual or hearing a call, a GPS recording of the location of that individual was made at a perpendicular distance from the boat, the distance estimated, and photos of the habitats and species taken where possible. The survey started in early mornings between $800-900 \mathrm{hrs}$ of the sampling day, moving slowly downstream surveying one side of the channel, up to the mouth of the channel lakewards. At the turn around point, the survey continued on the opposite side of the channel until the start point, with daily surveys usually ending from 1300-1400. Reptiles basking on the banks of the river or floating on vegetation or in the river were counted and the activities they were involved in documented.

A standardized dip-net was used to scoop through aquatic habitats to sample for aquatic species and tadpoles. Specimens of aquatic species or tadpoles caught by this method, if not identifiable in the field were preserved for later identification in the lab.

At selected sites, pitfall traps were set up with a drift fence in the study area along land transects to sample any surface-dwelling herpetofauna (Dodd 1991; Mitchell et al. 1993; Heyer et al. 1994, Handley \& Varn 1994; Msuya 2001). Each drift fence consisted of eleven 20-liter plastic buckets placed at an interval of $10 \mathrm{~m}$, covering a total length of $100 \mathrm{~m}$. The buckets were placed in holes dug in the substrate using a hoe or pick-ax, such that their rim was level with the ground.

A 100-meter-long and 0.5-meter-high drift fence of black polythene supported vertically by wooden laths was set in an alternating manner with the 
buckets in the line, to permit detection of directional movements of species. The pitfall traps were inspected twice a day. This method was tried out once and abandoned because of logistical constraints; the array needed monitoring overnight to protect equipment from being stolen.

Pseudoreplication was avoided by surveying a single site only once during the surveys. So, we would exclude that the same individuals were observed more than once during our study. Opportunistic records are herein defined as those made outside the sampling time but that occurred in the surrounding area to be impacted by the project. These opportunistic records helped complete the checklist of the amphibians and reptiles as much as possible.

\subsection{Statistical analyses}

The data were sorted according to the transect and herpetofauna group using an excel spreadsheet. The cleaned data were exported to Microsoft access to perform more robust data filtering techniques to determine the species number in each group and transect. Biodiversity pro software was used to predict species occurrence and generating a species accumulation curve for each herpetofaunal group. To assess the diversity and species richness between sites, the functions "diversity" and "specnumber" in the Vegan R package (Oksanen, 2019) were used, whereas the "renyi" diversity function was used for graphical representation of diversities between the study sites.

\section{RESULTS \\ 3.1. Distribution and diversity of reptile species}

A total of 898 individuals representing 25 reptile species belonging to four orders (i.e. Chelonia, Sauria, Serpentes, and Crocodylia), 15 families, and 20 genera were recorded during the 12 months of surveys (Table S2). In terms of monthly variation in the diversity of observed species, October 2017 showed the highest reptilian diversity with 14 species, followed by January, March, July, and September 2018 (10 species each) (Fig. 2a) (raw data in Table S3).

The most frequently observed species were: $\mathrm{Va}$ ranus niloticus $(\mathrm{n}=361)$, Crocodylus niloticus (n = 191), Agama agama ( $\mathrm{n}=172$ individuals), and Trachylepis maculilabris $(\mathrm{n}=78)$ and each of them was recorded every month of the survey. These four species accounted for about $89.3 \%$ of all individuals recorded in the study area. (a)

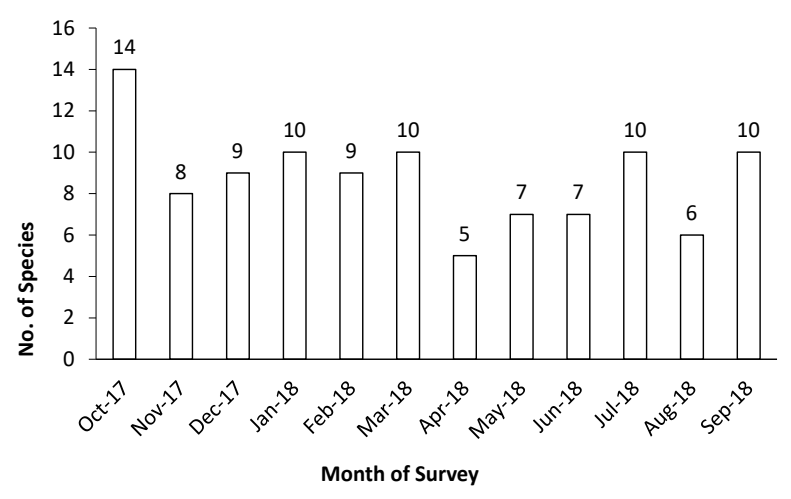

(b)

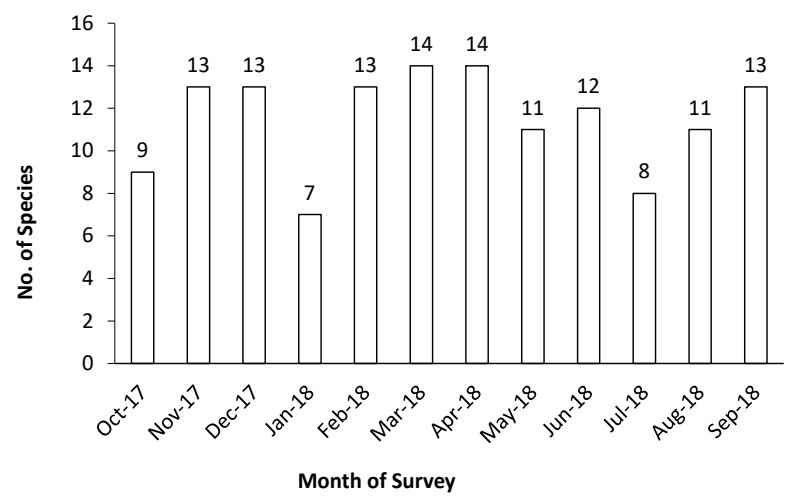

Figure 2: Species richness for reptiles (a) and amphibians (b) over the 12-month survey period in the Murchison Falls-Lake Albert Delta Wetland System.

\subsubsection{Temporal and spatial species diversity and richness for reptiles}

The month of June 2018 had the highest combined number of individual reptiles sighted of all months (105 individuals), followed by the months of January and February (90 and 94 respectively), while October (46), November and March (53 each) showed the least combined number of individuals sighted. Across transects, Land Transect South (LTS) showed the highest species richness and diversity (21 species and 5.23 Simpson diversity index), followed by Land Transect North (LTS) (17spp, 3.72 Simpson diversity index), while delta mid-channel trailed (4 spp, Simpson diversity index 1.78 (Fig. 3a, (Tab. S5). Although Land Transect South had the highest species richness and diversity, it trailed below Delta Channel North in terms of relative species abundance by $12.7 \%$. This was attributed to the numerous observations of Varanus niloticus which altered the over- 


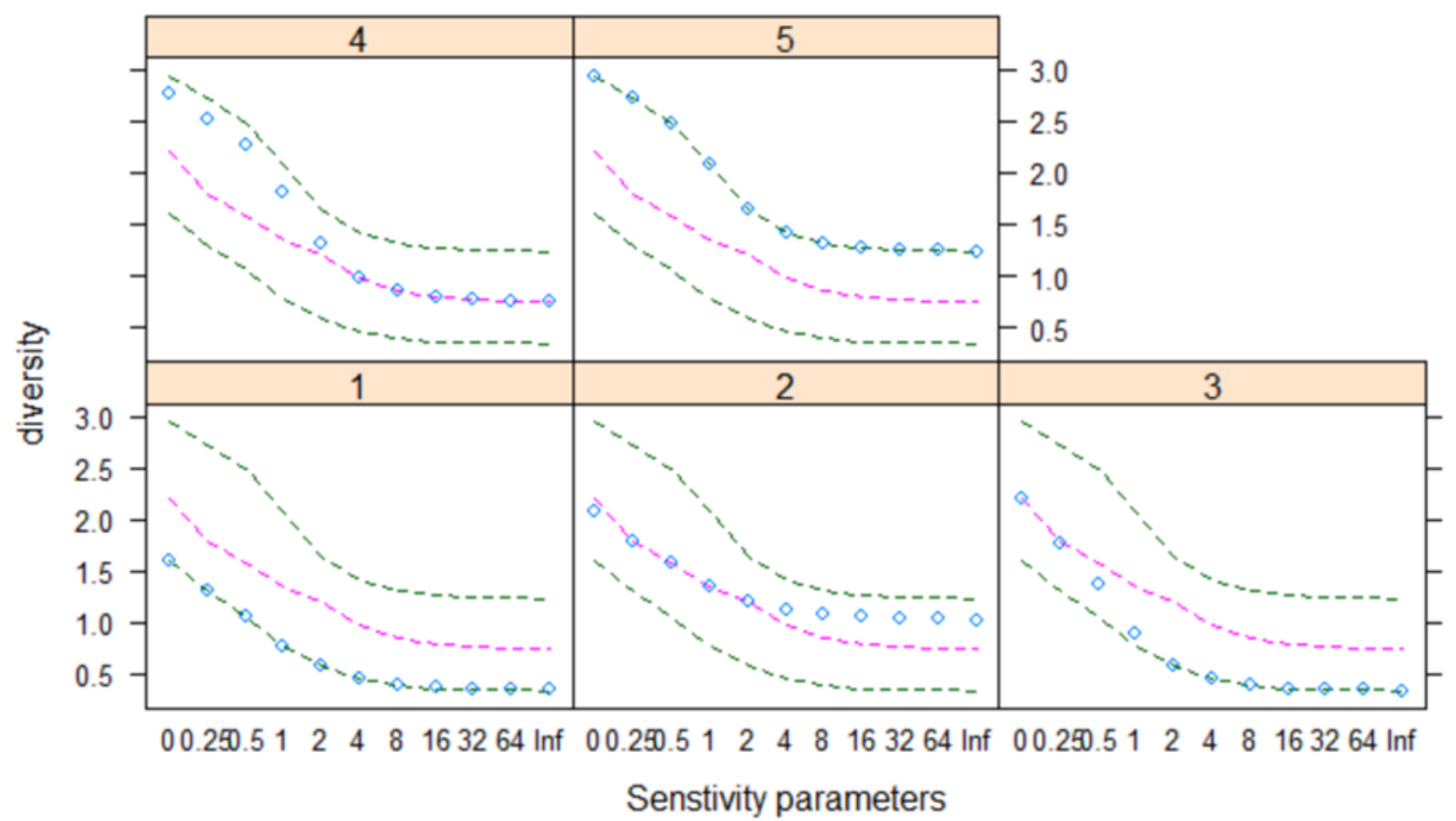

Figure 3a: Renyi diversities for reptiles in 5 sites (transects).

(Where 1 = Delta Channel Mid (DCM), 2 = Delta Channel North (DCN), 3 = Delta Channel South (DCS), 4 = Land Transect North (LTN), 5 = Land Transect South (LTS). Renyi diversities for reptiles in 5 sites (transects). Land Transect North and Land Transect South are more diverse than the remaining three sites. Diversity index Values at each site are represented by dots while the median and the extremes are represented by the lines. When the sensitivity parameter on the $\mathrm{x}-$ axis is 0 the corresponding value is the species number at a given site, at 1, the conforming value is exponential Shannon (expH') and the corresponding value at sensitivity parameter 2 is the 2 is the inverse Simpson (1/D) while the conforming value of Inf is the inverse relative dominance (1/P1).

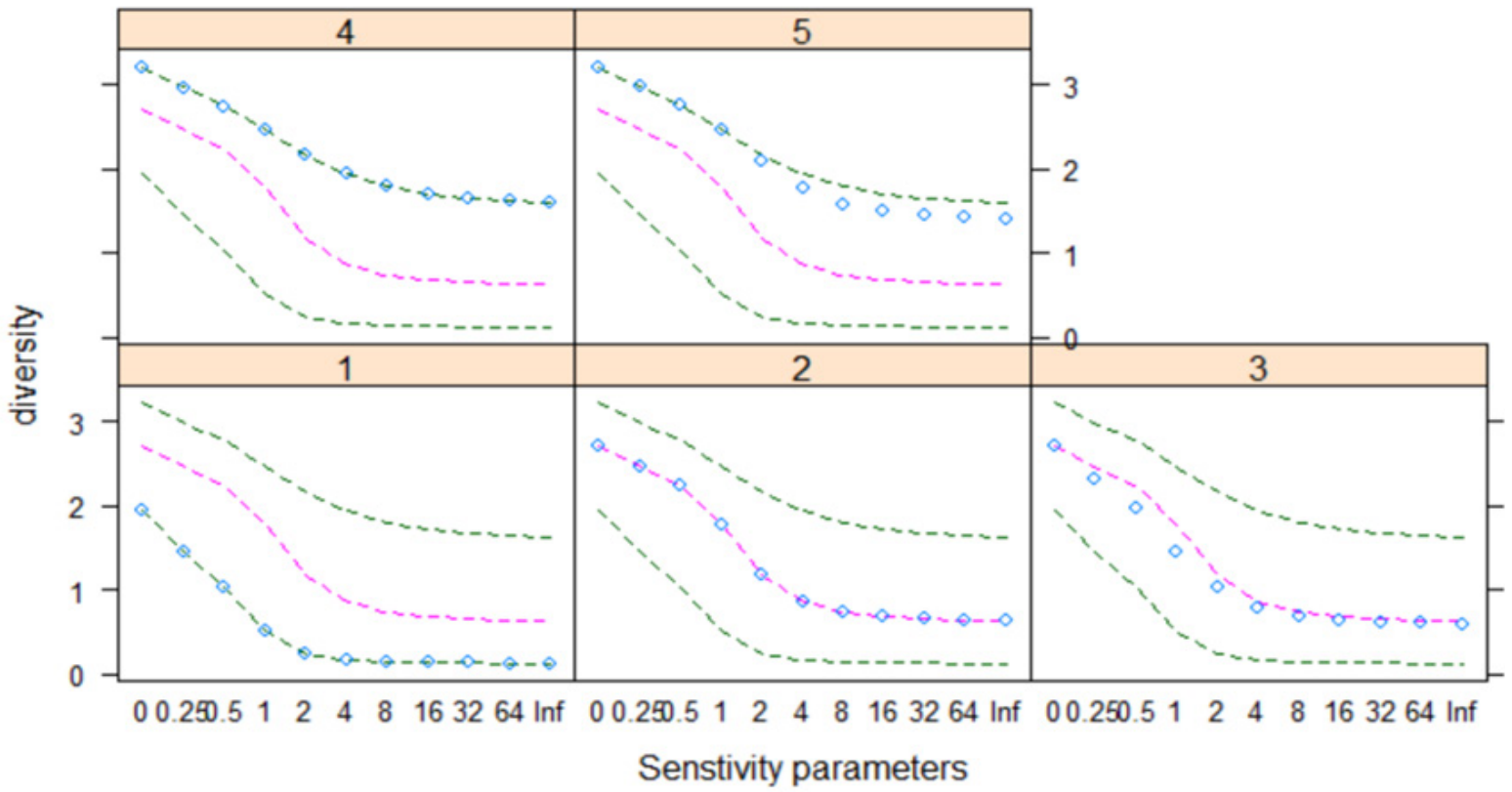

Figure 3b: Renyi diversities for amphibians in 5 sites (transects).

Land Transect South and land Transect North are more diverse than all other sites. Diversity index Values at each site are represented by dots while the median and the extremes are represented by the lines. When the sensitivity parameter on the $\mathrm{x}$ - axis is 0 the corresponding value is the species number at a given site, at 1 , the conforming value is exponential Shannon (expH') and the corresponding value at sensitivity parameter 2 is the 2 is the inverse Simpson (1/D) while the conforming value of Inf is the inverse relative dominance (1/P1). 
all evenness. Land Transect North (LTN) and Delta Channel Mid (DCM) had the lowest relative abundances (13.9\% and $14.7 \%$ respectively)

A species accumulation curve for reptiles plotted showed that a plateau phase was not yet reached (Fig. 4 a). This suggests that the reptilian diversity of the surveyed sites had not been exhausted, and with more time and/or effort and more habitats surveyed, more species would have been added. Species diversity estimators Chaol predicted the occurrence of 25 species, Chao2 predicted 36 species, Jacknife1 up to
32 species while Jacknife 2 predicted 36 species at its highest peak. The most conservative estimators for this analysis were Chaol and Jacknife1, predicting up to 32 species. Chaol and Jacknife1 graphs were also still rising, meaning the species estimated could still increase with more surveys.

\subsection{Distribution and diversity of amphibian species}

A total of 315 individuals from 27 amphibian species, all of order Anura, belonging to nine fam-

\section{(a)}

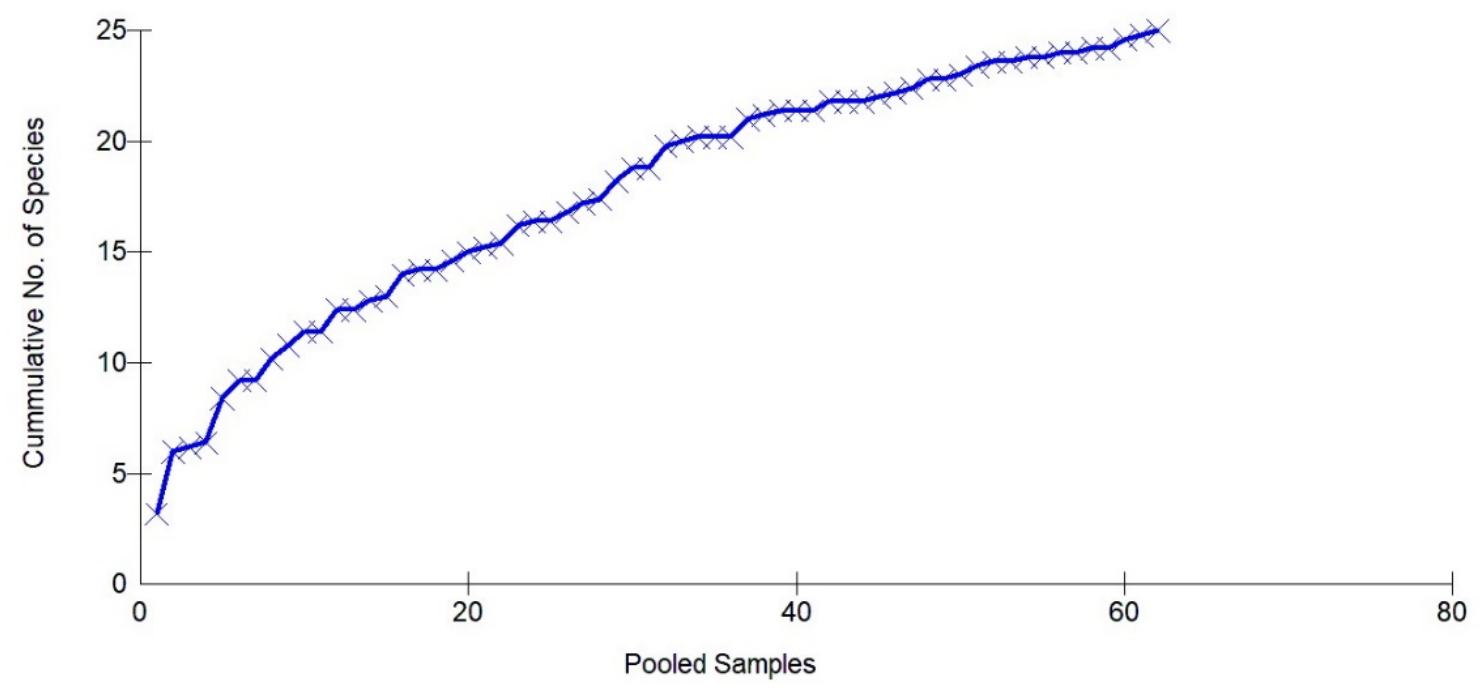

(b)

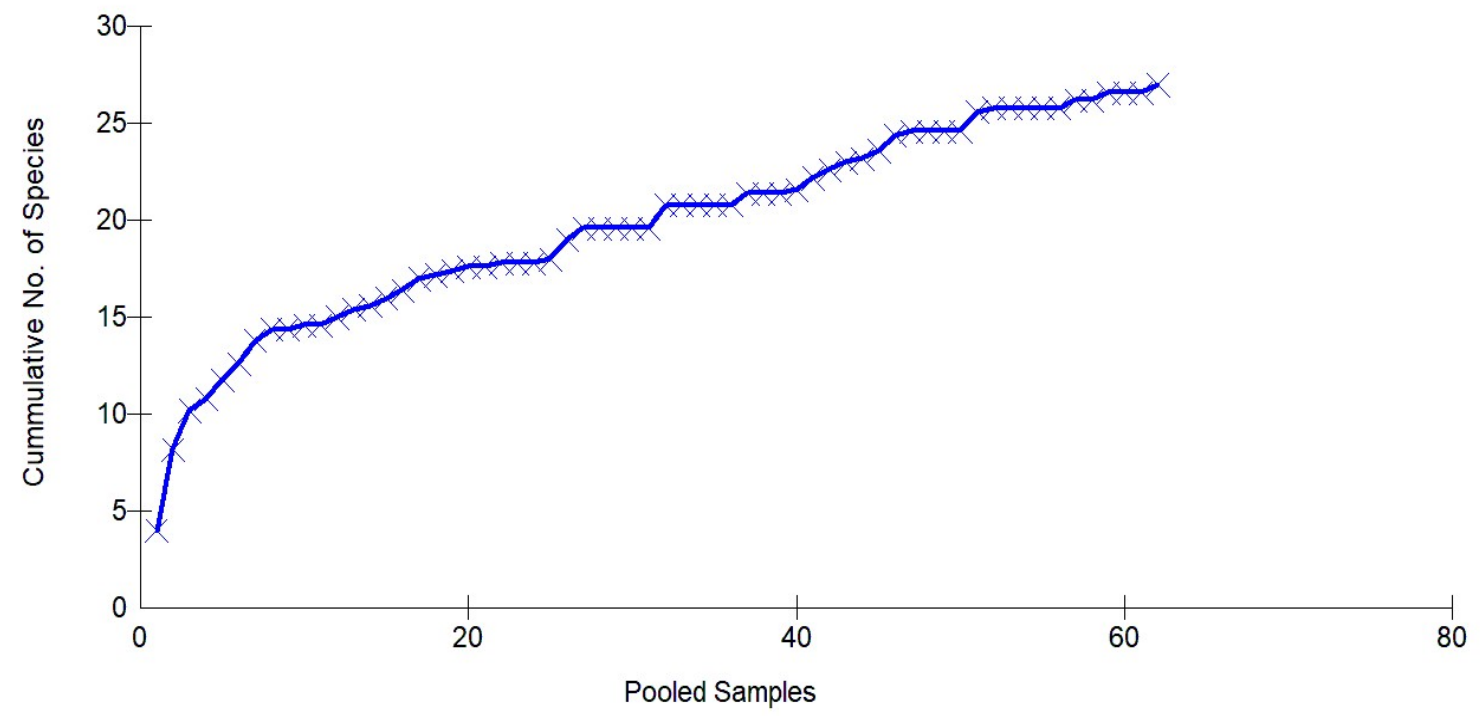

Figure 4: Species accumulation curve for reptiles (a) and amphibians (graphic (b) over the 12 months of survey in the Murchison Falls-Lake Albert Delta Wetland System. 
ilies and 10 genera were recorded during the 12 months of surveys (Table S4). Phrynobatrachus bullans and Phrynabtrachus natalensis were the most dominant species with a relative abundance of $34.3 \%$ and $15.6 \%$ respectively while Hyperolius microps, Hyperolius viridiflavus bayoni, Phrynobatrachus sp. 1, Ptychadena cf. aequiplicata, Sclerophrys pusilla and Xenopus victorianus had a very low relative abundance $(0.3 \%)$ since each was recorded once in the study sites hence (Table S8). In general, only nine species accounted for $91 \%$ of all individuals recorded in the study area. An indication of rarity in the study area, where many species are not common, but a few are abundant.

\subsubsection{Temporal and spatial species diversity and richness for amphibians}

Species abundance varied markedly across the year. April 2018 emerged with the highest number of individuals of amphibians (791), followed by December, September and November (587, 540, and 404 respectively) (Table S5). A few species were recorded every month during the study period namely - Phrynobatrachus bullans, Phrynobatrachus sp. 2, and Phrynobatrachus natalensis, together with Ptychadena nilotica. Both Hoplobatrachus occipitalis and Sclerophrys vittata were recorded for 11 months. The months of March and April 2018 had the highest species richness with 14 species each, followed by November and December 2017, February and September 2018 (13 spp each), then June (12 spp), May and August (11 spp each) (Fig. 2b, Table S5). LTS registered the highest species diversity, richness and relative abundance followed by LTN while DCM had the lowest species diversity and richness but registered a higher relative abundance than the DCN (Tab. S6). This points to the fact that in DCN, one species (Phrynobatrachus bullans) was more common and very abundant than the remaining three species.

A species accumulation curve plotted for amphibians showed that the plateau phase was not yet reached (Fig. 3b). Species estimators Chao1, Chao2, Jacknife1, and Jacknife2 put the maximum number of species in the survey area up to 88 , with Chao 1 agreeing with the current number of 27 , while Chao 2 gives an erratic number of 88 species; Jacknife1 and Jacknife 2 predict up to 38 and 48 species respectively. Chao1 and Jacknife1 predicted a maximum of 38 amphibian species in the study area.

\section{Discussion}

Our study revealed that, as a general pattern, species diversity was highest at either end on the land transects, and lowest in the Delta Channel. Therefore, there was variation in species richness and diversity in both amphibians and reptiles in the various sectors of the study area. The occurrence of the least number of species in mid-channel was expected as most species we encountered do not utilize open water habitats. Species diversity was highest towards Land Transect South (LTS) and second-highest towards Land Transect North (LTN). The reason could be due to an increase in diversity as one moves towards land with anthropogenic disturbance thus favoring common and abundant species for Land Transect South (LTS) while the reverse is true as one moves toward the park which is a natural habitat that favors the more specialized species. There is literature evidence that species richness is correlated with habitat heterogeneity at the local scale (Lundholm \& Larson 2003; Báldi 2008). Stein et al. (2014) demonstrated that habitat heterogeneity is a major driver of species richness across taxa, biomes, and spatial scales. For reptiles, the species estimators predict up to 32 reptile species in the Delta Ramsar Area, thus despite the long research period (12 months) and the use of several independent survey methodologies, there may still be a considerable amount of species that remain undetected. The same was true, and even more evident, with regard to our surveys for amphibians (38 species predicted versus 27 species detected). Thus, our data showed that, at least in the high biodiverse areas of East Africa where surveys are logistically difficult, the recorded herpetofaunal community metrics can be substantially biased because of suboptimal species detection.

The seasonal reptile metrics across the months had a straightforward pattern: diversity peaked in the dry season, but an abundance of observed individuals peaked in the wet season. In amphibians, there were two peaks around the wet seasons (i.e. between October-December, and March-May). The diversity reaches low numbers during the dry season months. Whereas the diversity for reptiles seemed to be influenced by major habitat and time-of-day factors, the diversity for amphibians seemed to be influenced by the proximity to riverbanks. The diversity of amphibians was highest along transects from either bank because of the proximity to water and increased diversity of habitats. On the other hand, unlike for reptiles 
where January is the peak of reptilian diversity, the month which is the peak of the dry season recorded the lowest amphibian diversity. The diversity for amphibians starts to go down in May with the passing of the peak of the rainy season.

\subsection{Species of Conservation Concern and Critical Habitat Species}

Most of the species recorded according to IUCN (2020) are Not Evaluated (NE) or Least Concern (LC) (Table S2 and S4). The species Trionyx triunguis (regionally vulnerable -VuA4bcd) (van Dijk et al, 2017) and (Critically threatened nationally - CR B1 ab (i, ii, iii, iv)), Kinixys belliana, Trachylepis perrotetti, Crocodylus niloticus, Letheobia cf. sudanensis and Philothamnus bequaerti are reptilian species whose populations should be monitored to detect any eventual decline. All amphibian species reported are of Least Concern (LC) at national and global levels. However, Sclerophrys vittatus, Phrynomantis microps and Ptychadena schillukorum should be monitored because they are potentially vulnerable to declines.

In terms of Critical Habitats $(\mathrm{CH}$; sensu Stefan et al. 2013), banks with woody vegetation and papyrus dominated habitats, particularly along the Delta Channel North (DCN) are in greatest need of protection before and during any activities in the oil and gas industry. The ecotones between water and the land are critical habitats for herpetofaunal conservation and should be protected when carrying out any oil and gas activity.

\section{ACKNOWLEDGMENTS}

The research was funded by Total E\&P Uganda B.V. under a service contract to Biodiversity Solutions Limited (BSL). We thank the Uganda National Council of Science and Technology (UNCST) for granting research permits and the Uganda Wildlife Authority (UWA) for field support and permits to conduct this research in Murchison Falls National Park. We also acknowledge the field assistance by Environmental and Biodiversity Field Officers (EBFOs), Community Liaison Officers (CLOs), UWA Rangers, and all other staff who contributed to the success of this research in one way or another. Great thanks to Michele Menegon from Trento Science Museum (Italy) who was very helpful in species id confirmation using DNA barcoding We are indebted to Aaron Bauer, Eli Greenbaum, and two anonymous referees for useful comments on the submitted draft.

\section{REFERENCES}

AmphibiaWeb (2017) Information on amphibian biology and conservation. Berkeley, California: http://amphibiaweb.org

Baguma, R.K. (1996) Some ecological aspects of the Nile crocodile (Crocodylus niloticus) in Murchison Falls National Park, Uganda. Masters Degree Programme Progress Report, Makerere University, 11/96, March, 1996.

Báldi, A. (2008). Habitat heterogeneity overrides the species-area relationship. Journal of Biogeography, 35(4), 675-681.

Behangana, M., Lukwago, W., Dendi, D., Luiselli, D. \& Ochanda, D. (2017) Population surveys of Nile crocodiles (Crocodylus niloticus) in the Murchison Falls National Park, Victoria Nile, Uganda. European Journal of Ecology, 3(2), 67-76,

Behangana, M (2014) A survey of crocodiles and other herpetofauna in the Victoria Nile/Ramsar Site of Murchison Falls National Park. A TEP Uganda Report, Kampala, Uganda.

Brauneder K.M, Montes, C., Blyth, S., Bennun, L., Butchart, S.H.M., Hoffmann, M., et al. (2018) Global screening for Critical Habitat in the terrestrial realm. PLoS ONE, 13(3), e0193102. DOI: 10.1371/journal. pone. 0193102

Channing, A. \& Howell, K.M. (2006) Amphibians of East Africa. Edition Chimaira.

Dodd, C.K. Jr. (1991) Drift fence associated sampling bias of amphibians at a Florida Sandhills temporary pond. Journal of Herpetology, 25, 296-301.

Dodd, C.K. Jr. (2016) Reptile Ecology and Conservation. A handbook of Technique. Oxford University Press

Games, I., Baguma, R.K., Buhanga, E. \& Babaasa, D. (1996) Uganda Crocodile Survey. A Report to the Uganda Wildlife Authority.

Handley, C.O. \& Varn, M. (1994) The trapline concept applied to pitfall arrays. Special publication of Carnegie Museum of Natural History, 18, 285-287.

Heyer, W.R., Donnely, M.A., Mc Diarmid, R.W., Hayek L.C. \& Foster, M.S. (Eds.). (1994) Measuring and Monitoring Biological Diversity: Standard Methods for Reptiles and Amphibians. Smithsonian Institution Press, Washington.

Hughes, D.F., Greenbaum, E. \& Behangana, M. (2017a) Expedition report from Uganda: Herpetological surveys at Bwindi Impenetrable National Park, Rwenzori Mountains National Park, and the Northern Shore of Lake Victoria. Unpublished report.avail- 
able at: <http://www.podarcis.de/AF/Bibliografie/ BIB_10674.pdf>

Hughes, D.F., Greenbaum, E., Lukwago, W. \& Behangana, M. (2017b) Expedition report from Uganda: Herpetological surveys at eight Central Forest reserves (Agoro-Agu, Budongo, Echuya, Mabira, Mount Kadam, Mount Kei, Mount Moroto, and Mount Otze) and four National Parks (Bwindi Impenetrable, Mgahinga Gorilla, Mount Elgon, and Rwenzori Mountains). Unpublished report available at: $<$ http://www.podarcis. de/AF/Bibliografie/BIB_10674.pdf $>$.

Hutton, J.M. (1991) Crocodiles and their management in the Murchison Falls National Park of Uganda. Agriconsulting/Uganda Institute of Ecology

IUCN (2020) IUCN Red List of Threatened Species. Version 2020.1. <Www.iucnredlist.org>.

Leaché, A.D., Grummer, J.A., Miller, M., Krishnan, S., Fujita, M.K., Böhme, W., et al. (2017) Bayesian inference of species diffusion in the West African Agama agama species group (Reptilia, Agamidae). Systematics and Biodiversity, 15(3), 192-203.

Lundholm, J.T. \& Larson, D.W. (2003). Relationships between spatial environmental heterogeneity and plant species diversity on a limestone pavement. Ecography, 26(6), 715-722.

Mitchell, J.C., Erdle, S.Y. \& Pagels, J.F. (1993) Evaluation of capture techniques for amphibians, reptiles, and small mammal communities in the saturated forested wetlands. Wetlands, 13, Special issue, 130-136.

Msuya, C.A. (2001) Habitats, distribution and feeding of amphibians in Zaraninge Forest Reserve, Tanzania. A case study of the ecology of a community of amphibians in coastal forest ecosystem in Bagamoyo District, Tanzania. PhD Thesis, University of Dar es Salaam.

Oksanen, J.F., Blanchet, G., Friendly, M., Kindt, R., Legendre, P-, McGlinn, D., et al. (2019). Vegan: Community Ecology Package. R package version 2.5-6. https://CRAN.R-project.org/package=vegan

Parker I.S.C. (1969) Crocodile distribution and status in the major waters of western and central Uganda. Afr. J. Ecol., 8(1): 85-103

Parker, I.S.C. \& Watson, R.M. (1970) Crocodile Distribution and Status in the Major Waters of Western and Central Uganda in 1969. E. Afr. Wildl. J., 8:85-103.

Peel, M.C, Finlayson, B.L. \& Mcmahon, T.A. (2007) Updated world map of the Köppen-Geiger climate classification. Hydrology and Earth System Sciences Discussions, European Geosciences Union, 4(2), 439-473.
Plumptre, A.J., Ayebare, S., Mugabe, H., Kirunda, B., Kityo, R., Waswa, S., et al. (2015) Biodiversity Surveys of Murchison Falls Protected Area. WCS, Kampala, Uganda.

Plumptre, A.J, Davenport, T.R.B., Behangana, M., Kityo, R., Eilu, G., Ssegawa, P. et al. (2007), The biodiversity of the Albertine Rift. Biol. Cons., 134, 178-194.

Rhodin, A.G.J., Iverson, J.B., Bour, R., Fritz, U., Georges, A., Shaffer, H.B., et al. (2017) Turtles of the world: Annotated checklist and atlas of taxonomy, synonymy, distribution, and conservation status (8th Ed.). In: A.G.J. Rhodin, J.B. Iverson, P.P. van Dijk, R.A. Saumure, K.A. Buhlmann, P.C.H. Pritchard et al. (Eds.). Conservation biology of freshwater turtles and tortoises: A compilation project of the IUCN/SSC Tortoise and freshwater turtle specialist group. Chelonian Research Monographs, 7, 1-292. DOI: 10.3854/ crm.7.checklist.atlas.v8.2017.

Schiøtz, A. (1999) Treefrogs of Africa. Edition Chimaira, Frankfurt am Main.

Spawls, S., Howell, K. \& Drewes, C. (2006) Pocket guide to the reptiles and amphibians of East Africa. A \& C Black Publishers, London.

Spawls, S., Howels, K., Drewes, C. \& Ashe, J. (2002) A field guide to the reptiles of East Africa. A \& C Black Publishers, London and San Diego.

Spawls, S., Howell, K., Hinkel, H. \& Menegon, M. (2018) Field guide to east African Reptiles. 2nd Ed. Bloomsbury Publishing Plc.

Stefan, C.I., Robichaud, C., Knopff, K., Nielsen, D., Carveth, C., Melton, D., et al. (2013) Critical habitat assessment using IFC PS6 Criteria. Presented at IAIA13, the 33rd Annual IAIA Conference, 13-16 May 2013 in Calgary, Alberta, Canada.

Stein, A., Gerstner, K. \& Kreft, H. (2014). Environmental heterogeneity as a universal driver of species richness across taxa, biomes and spatial scales. Ecology Letters, 17(7), 866-880.

TBC \& FFI (2016) (in prep). Critical habitat assessment: Results and interpretation. Report on behalf of Total E\&P Uganda, Block EA1, EA1A and EA2 North.

Thorbjarnarson, J. \& Shirley, M.H. (2009) Observations on Nile Crocodiles (Crocodylus niloticus) and their management in Murchison Falls National Park. A Report to the Wildlife Conservation Society and the Uganda Wildlife Authority, Kampala, Uganda.

TUOP (2015) Phase 2 Biodiversity Study. Landcover mapping for the Albertine Rift oil development basin, exploration areas EA1-3. Interim Report. Unpublished. 
Uetz, P. \& Hošek, J. (Eds.) (2018) The Reptile Database, http://www.reptile-database.org

van Dijk, P.P., Diagne, T., Luiselli, L., Baker, P.J., Turkozan, O. \& Taskavak, E. 2017. Trionyx triunguis. The IUCN Red List of Threatened Species 2017: e. T62256A96894956. http://dx.doi.org/10.2305/IUCN. UK.2017-3.RLTS.T62256A96894956.en

WCS \& eCountability (2016) Phase 2 Biodiversity Study

- Critical Habitat Assessment, Prepared for Tullow Uganda Operations PTY
WCS \& eCountability (2016) Volume 3, Biodiversity surveys of EA2: Fieldwork data and analysis, Prepared for Tullow Uganda Operations PTY

WCS (2016) Nationally threatened species for Uganda. National Red List for Uganda for the following taxa: Mammals, birds, reptiles, amphibians, butterflies, dragonflies and vascular plants. Prepared by WCS, the Government of Uganda, the Uganda Wildlife Authority. 


\section{Online Supplementary Materials}

Table S1. Transects surveyed for herpetofauna with their start and end points, at the study area.

\begin{tabular}{|c|c|c|c|c|}
\hline Transect Name & Code & Location & Coordinates & $\begin{array}{l}\text { Approximate } \\
\text { Length }(\mathrm{km})\end{array}$ \\
\hline Land Transect North & $\mathrm{LN}$ & $\begin{array}{l}\text { Circumferenced by road from Hip- } \\
\text { po pool, along Shoebill track to } \\
\text { Buligi track on Pipeline Crossing } \\
\text { North (PCN) }\end{array}$ & $\begin{array}{l}\text { From N2.26994 E31.37618 } \\
\text { to N2.25520 E31.49560 }\end{array}$ & 20 \\
\hline Land Transect South & LS & $\begin{array}{l}\text { From Wanseko town outskirts (Ka- } \\
\text { tanga) to Kasinyi village - delineat- } \\
\text { ed by road parallel to the river }\end{array}$ & $\begin{array}{l}\text { From N2.18679 E31.38752 to } \\
\text { N2.22285 E31.45043 }\end{array}$ & 10 \\
\hline $\begin{array}{l}\text { Delta Channel North } \\
\text { Transect }\end{array}$ & $\mathrm{DN}$ & $\begin{array}{l}\text { Channel transect where river hugs } \\
\text { the Northern bank }\end{array}$ & $\begin{array}{l}\text { From N2.25303 E31.48686 to } \\
\text { N2.27092 E31.37122 }\end{array}$ & 20 \\
\hline $\begin{array}{l}\text { Delta Channel Mid Tran- } \\
\text { sect }\end{array}$ & $\mathrm{DM}$ & $\begin{array}{l}\text { Longest distance starts where the } \\
\text { river splits into two main channels }\end{array}$ & $\begin{array}{llll}\text { From N2.22975 E31.44260 to } \\
\text { N2.23835 E31.36091 }\end{array}$ & 10 \\
\hline $\begin{array}{l}\text { Delta Channel South } \\
\text { Transect }\end{array}$ & DS & $\begin{array}{l}\text { Channel transect where river hugs } \\
\text { the Southern bank }\end{array}$ & $\begin{array}{l}\text { From N2.24807 E31.49746 to } \\
\text { N2.18350 E31.37459 }\end{array}$ & 20 \\
\hline
\end{tabular}

NB: The distances only refer to the navigable parts of the river by the small boat. 


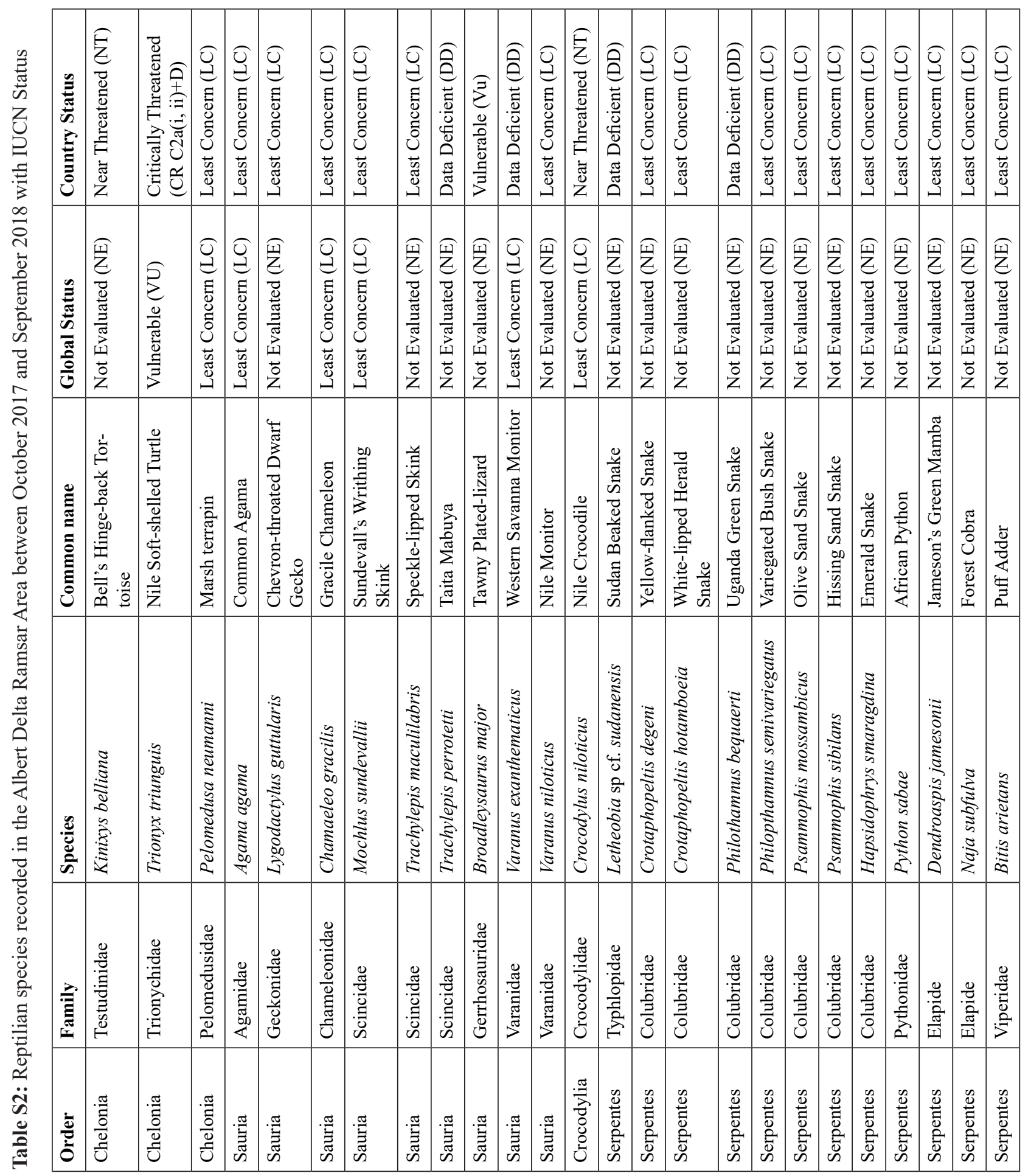




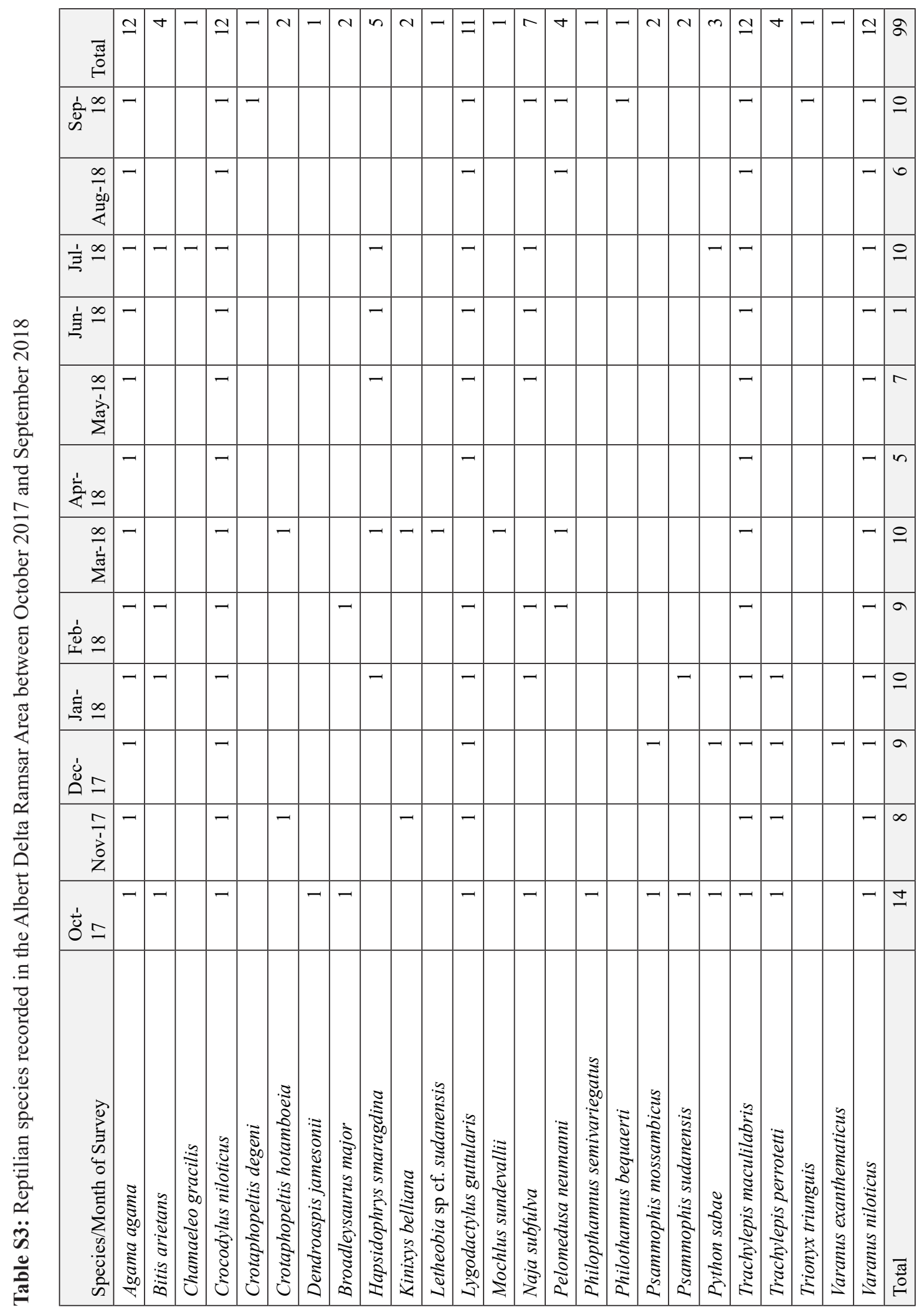


Table S4: Amphibian species recorded in the Albert Delta Ramsar Area between October 2017 and September 2018 with IUCN Status.

\begin{tabular}{|c|c|c|c|c|}
\hline Family & Species & Common name & Global Status & Country Status \\
\hline Pyxicephalidae & Amietia nutti & & Least Concern (LC) & Least Concern (LC) \\
\hline Bufonidae & Sclerophrys gutturalis & Guttural Toad & Least Concern (LC) & Least Concern (LC) \\
\hline Bufonidae & Sclerophrys regularis & Common Toad & Least Concern (LC) & Least Concern (LC) \\
\hline Bufonidae & Sclerophrys vittata & Lake Victoria Toad & Data Deficient (DD) & Least Concern (LC) \\
\hline Bufonidae & Sclerophrys pusilla & Flat-backed Toad & Least Concern (LC) & Data Deficient \\
\hline Dicroglossidae & Hoplobatrachus occipitalis & Crowned Bullfrog & Least Concern (LC) & Least Concern (LC) \\
\hline Hemisotidae & Hemisus marmoratus & Shovel-nosed Frog & Least Concern (LC) & Least Concern (LC) \\
\hline Hyperoliidae & Afrixalus quadrivittatus & Four-lined Spiny Reed Frog & Least Concern (LC) & Least Concern (LC) \\
\hline Hyperoliidae & Hyperolius microps & $\begin{array}{l}\text { Sharp-headed Long Reed } \\
\text { Frog }\end{array}$ & Least Concern (LC) & Least Concern (LC) \\
\hline Hyperoliidae & $\begin{array}{l}\text { Hyperolius cinnamome- } \\
\text { oventris species complex }\end{array}$ & Cinnamon-bellied Reed Frog & Least Concern (LC) & Least Concern (LC) \\
\hline Hyperoliidae & Hyperolius kivuensis & Kivu Reed Frog & Least Concern (LC) & Least Concern (LC) \\
\hline Hyperoliidae & Hyperolius v. bayoni & Bayoni's Reed Frog & Least Concern (LC) & Least Concern (LC) \\
\hline Hyperoliidae & Hyperolius v. viridiflavus & Common Reed Frog & Least Concern (LC) & Least Concern (LC) \\
\hline Phrynobatrachidae & Phrynobatrachus bullans & Bubbling puddle frog & Least Concern (LC) & Data Deficient (DD) \\
\hline Phrynobatrachidae & Phrynobatrachus sp. 1 & & & \\
\hline Phrynobatrachidae & $\begin{array}{l}\text { Phrynobatrachus } \\
\text { natalensis }\end{array}$ & Natal Dwarf Puddle Frog & Least Concern (LC) & Least Concern (LC) \\
\hline Phrynobatrachidae & Phrynobatrachus sp. 2 & & & \\
\hline Phrynobatrachidae & Phrynobatrachus sp.3 & & & \\
\hline Microhylidae & Phrynomantis microps & West African Rubbber Frog & Least Concern (LC) & Data Deficient (DD) \\
\hline Ptychadenidae & Ptychadena anchietae & Anchieta's Ridged Frog & Least Concern (LC) & Least Concern (LC) \\
\hline Ptychadenidae & $\begin{array}{l}\text { Ptychadena sp. } \\
\text { cf.aequiplicata }\end{array}$ & Victoria Grassland Frog & Least Concern (LC) & Data Deficient (DD) \\
\hline Ptychadenidae & Ptychadena nilotica & Nile Grass Frog & Least Concern (LC) & Least Concern (LC) \\
\hline Ptychadenidae & Ptychadena oxyrhynchus & Sharp-nosed Ridged Frog & Least Concern (LC) & Least Concern (LC) \\
\hline Ptychadenidae & Ptychadena porosissima & Grassland Ridged Frog & Least Concern (LC) & Least Concern (LC) \\
\hline Ptychadenidae & Ptychadena Sp. & & & \\
\hline Ptychadenidae & Ptychadena schillukorum & Sudan Grassland Frog & Least Concern (LC) & Data Deficient (DD) \\
\hline Pipidae & Xenopus victorianus & Lake Victoria Clawed Frog & Least Concern (LC) & Least Concern (LC) \\
\hline
\end{tabular}


Table S5: Species richness and diversity of reptiles in the Delta Area of the Murchison Falls-Albert Delta Ramsar Site, Uganda

\begin{tabular}{|c|c|c|c|c|c|}
\hline $\begin{array}{c}\text { Delta area or } \\
\text { transect }\end{array}$ & $\begin{array}{c}\text { Simpson reciprocal } \\
\text { index }\end{array}$ & Species richness & $\begin{array}{c}\text { Relative abundance } \\
(\%)\end{array}$ & Pielou's J evenness & Shannon index \\
\hline DCM & 1.78 & 4 & 13.9 & 0.37 & 0.74 \\
\hline DCN & 3.37 & 8 & 31.5 & 0.89 & 1.33 \\
\hline DCS & 1.90 & 15 & 20.9 & 0.70 & 0.82 \\
\hline LTN & 3.72 & 17 & 14.7 & 0.90 & 1.74 \\
\hline LTS & 5.23 & 21 & 18.8 & 0.85 & 2.01 \\
\hline
\end{tabular}

Table S6: Species richness and diversity of amphibians in the Delta Area of the Murchison Falls-Albert Delta Ramsar Site, Uganda

\begin{tabular}{|c|c|c|c|c|c|}
\hline $\begin{array}{c}\text { Delta area or } \\
\text { transect }\end{array}$ & $\begin{array}{c}\text { Simpson reciprocal } \\
\text { index }\end{array}$ & Species richness & $\begin{array}{c}\text { Relative abundance } \\
(\%)\end{array}$ & Pielou's J evenness & Shannon index \\
\hline DCM & 1.29 & 04 & 14.44 & 0.28 & 0.51 \\
\hline DCN & 3.21 & 12 & 7.68 & 0.66 & 1.74 \\
\hline DCS & 2.76 & 12 & 23.29 & 0.54 & 1.45 \\
\hline LTN & 8.06 & 19 & 21.30 & 0.77 & 2.44 \\
\hline LTS & 8.09 & 23 & 33.28 & 0.77 & 2.46 \\
\hline
\end{tabular}




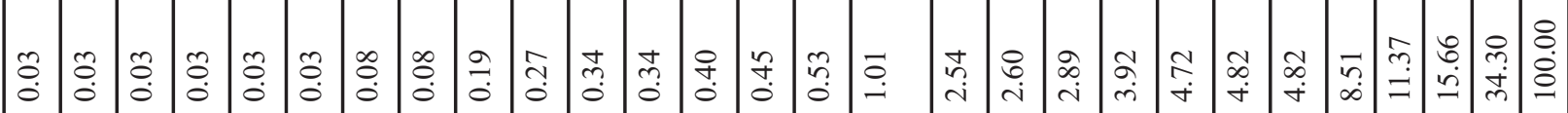

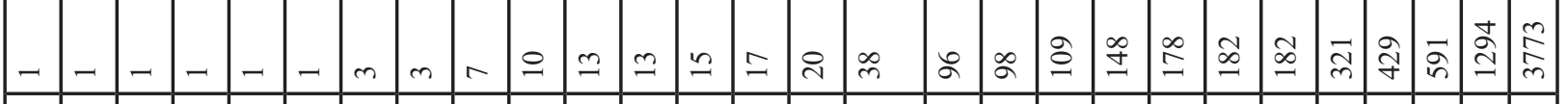

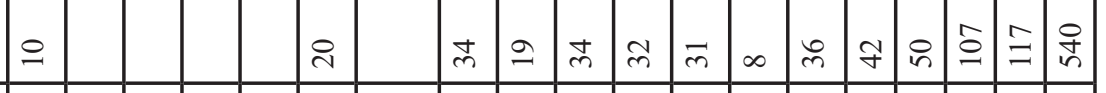

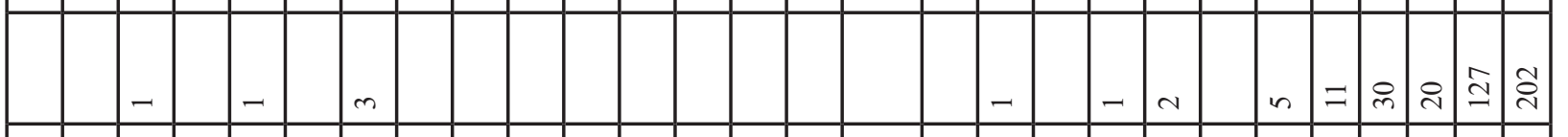

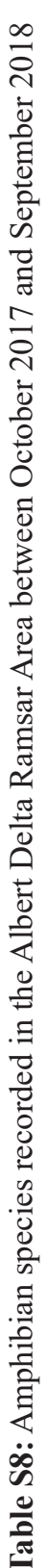

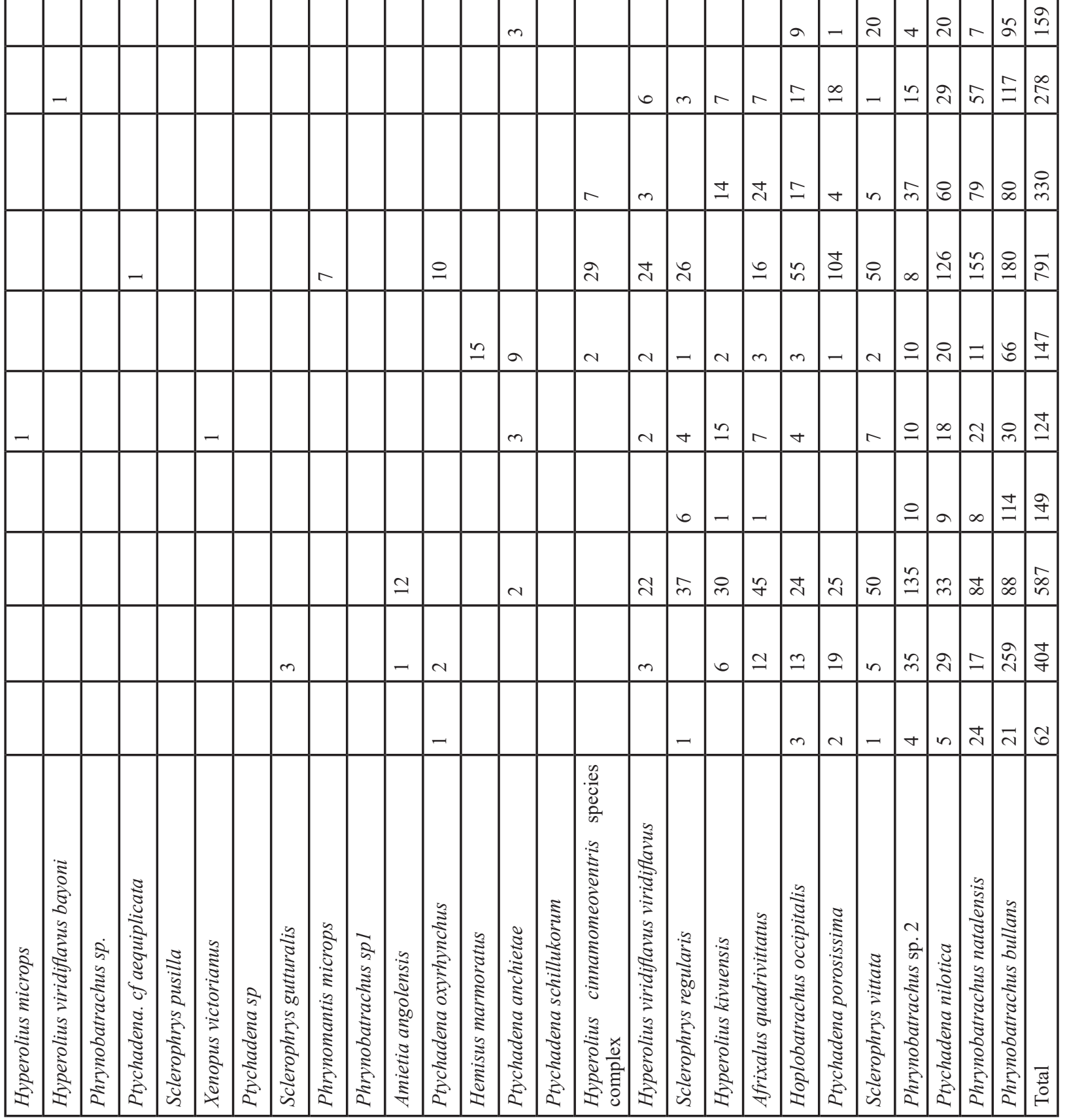

